\title{
Staging the Outcast in Brendan Behan's Three Prison Dramas
}

\author{
Wei H. Kao \\ National Taiwan University, Taiwan
}

Copyright (c) 2020 by Wei H. Kao. This text may be archived and redistributed both in electronic form and in hard copy, provided that the author and journal are properly cited and no fee is charged for access.

\begin{abstract}
Brendan Behan's portraits of the Irish Republican Army and the working-class community brought many previously unseen characters to light, including prison inmates, prostitutes, homosexuals and so forth. However, the most notable aspect of Behan's dramas is not necessarily the realistic approach by which most Irish playwrights have delineated social plights, but his meta-theatrical manner, alongside ensuing alienation effects, that keep audiences critically aware of a highly politicized and sectarian society. Behan consistently attempts to unsettle nationalist propaganda, gender biases and the puritanical narrative that the state/church apparatus had reinforced. His depictions of prisons that rarely receive public exposure challenge the binary perception of being either a martyr or a betrayer, a terrorist or a pacifist, and a moral or immoral being. Given that the young Behan had been jailed in both England and Ireland for supporting republican causes, he was able to offer a personal yet revisionist view of prisoners from different political persuasions and cultural backgrounds. The three prison dramas to be discussed are The Quare Fellow (1954), The Hostage (1958) and Borstal Boy (1967) - the final one being a posthumous adaptation of Behan's novel. These plays map out an alternative viewpoint of Ireland from within and beyond political imprisonment, and last but not least, Behan's theatrical legacy.
\end{abstract}

Key Words. Brendan Behan, Prison, Irish theatre, The Quare Fellow, The Hostage, Borstal Boy.

Resumen. Las representaciones de Brendan Behan del Ejército Republicano Irlandés y la clase trabajadora sacaron a la luz muchos personajes nunca antes vistos, incluidos los reclusos, las prostitutas, los homosexuales, etc. Sin embargo, el aspecto más notable del teatro de Behan no es necesariamente el enfoque realista por el cual la mayoría de los dramaturgos irlandeses han delineado las dificultades sociales, sino su forma meta-teatral, junto con los consiguientes efectos de alienación, que mantienen al público consciente de una sociedad altamente politizada y sectaria. Behan intenta constantemente perturbar la propaganda nacionalista, los prejuicios de género y la narrativa puritana que el aparato estatal/eclesiástico había reforzado. Sus representaciones de las cárceles que rara vez reciben exposición pública desafían la percepción 
binaria de ser un mártir o un traidor, un terrorista o un pacifista, y un ser moral o inmoral. Dado que el joven Behan había sido encarcelado tanto en Inglaterra como en Irlanda por apoyar causas republicanas, pudo ofrecer una visión personal pero también revisionista de prisioneros de diferentes tendencias políticas y antecedentes culturales. Los tres dramas que se discutirán son The Quare Fellow (1954), The Hostage (1958) y Borstal Boy (1967), siendo el último una adaptación póstuma de la novela de Behan. Estas obras trazan un punto de vista alternativo de Irlanda desde dentro y más allá del encarcelamiento político y, por último, pero no menos importante, el legado teatral de Behan.

Palabras clave. Brendan Behan, prisión, teatro irlandés, The Quare Fellow, The Hostage, Borstal Boy.

Historians and those who attempt to document the history of a community in a comprehensive and coherent manner must select and narrate their facts carefully so as to produce an interpretation that is acceptable to the majority of the public. To reach this end potential divergences of opinion might need to be overlooked or downplayed. However, this approach is equivocal to postmodern critics, in that how facts are collected and interpreted can never reach a final agreed format. This is particularly true as regards Ireland, because both nationalist and revisionist historians have their preferred yet often conflicting interpretations of history. Although their preconceived notions might be useful for shaping and narrating their past, this corresponds to Terry Eagleton's assertion that history "is not a monolithic phenomenon" because "there are always [different] currents within it [that are] construed and recollected in a certain way (13). Moreover, since few historical interpretations can be truly transcendental and objective, even if they are not denied politically, it is only when incompatible viewpoints are displayed that the public can develop multiple lines when thinking of their shared story. Notably, the theatre provides a unique platform for approaching history and current affairs, as a place where audiences can experience, directly and dispassionately, neglected or unsettling issues.

Among Irish playwrights who have tackled social and political issues critically, Brendan Behan (1923-1964), a self-taught working-class playwright who had been jailed for actively promoting republican causes in England and Ireland, unveiled the ignored experiences of prison inmates surviving in a particular social corner. One of the breakthroughs that Behan brought to the Irish theatre was his presentation of previously less seen characters, in response to J.M. Synge's and O'Casey's agendas for staging Aran Islanders and Dublin's urban poor respectively, and echoing W.B. Yeats's call to "express a life that has never found expression" (Synge 63). Coincidentally, these playwrights not only revised the artistic tastes of their time but redrew the boundaries between the politically advantaged and disadvantaged.

The three plays to be discussed - The Quare Fellow (1954), The Hostage (1958) and Borstal Boy (1967) - were written in the 1950s and 60s, ahead of the fierce revisionist debates of the 70 s. $^{1}$ The three plays are coherent in terms not only of their subject matters but also as critiques of the republican ideologies that misled political prisoners. Furthermore, with Bertolt Brecht's alienation effects occasionally used in these three plays - which have not been examined by critics as a whole - audience members are able to observe not only conflicts inside and outside of the prison but "the direct intention of the character who is speaking, and the refracted intention of the author" (Bakhtin 234). ${ }^{2}$ Notably, with the presentation of doublevoiced realities, as Richard Hornby defines metatheatre, or metafiction in drama, or "drama about drama," the trilogy reveals how the playwright intends to stage his prison experiences yet at the same time question the hidden political mechanisms behind bars (Hornby 31). 
As interrogative texts that do not specifically endorse any political persuasion, these prison plays, as a trilogy, impose no single privileged discourse but, to differing extents, pose more than critical questions regarding the consequences of political violence. This essay will examine not only Behan's rethinking of Irish politics but also the relationship between Irish drama and the real world outside the theatre, and in particular, how Behan theatrically seeks to dismiss the fourth wall of the stage with an "enquiring critical attitude" towards Irish republicanism (Brecht 106). In addition, it will illustrate how political antagonism may subjugate social minorities and manipulates a patriotic yet problematic rhetoric.

\section{The Quare Fellow (1954): Behind-the-scenes Characters Matter}

Alongside Samuel Beckett's Waiting for Godot (1953) and John Osborne's Look Back in Anger (1956), Behan's The Quare Fellow was regarded as having "inaugurate[d] the contemporary movement in Irish and British drama" (Hawkins 23). Keeneth Tynan, among others, gave high praise to this play because its "language is out on a spree, ribald, dauntless and spoiling for a fight ... [which] save[d] the English theatre from inarticulate glumness" (11). It can be assumed that perhaps because the playwright was not as prolific as Beckett and Osborne and died at the age of forty-one, whether he could have inaugurated another chapter in the history of English theatre is a topic that remains largely unexplored.

Similarly to the working-class characters in Look Back in Anger and tramps in Waiting for Godot, prisoners in The Quare Fellow, having been labelled as criminals by the state, are also politically hushed and pushed to the margins of the social spectrum. However, it is important to note that Behan's portraits of inmates, executioners, warders and the prison governor are largely due to personal experience based on his eight-year imprisonment in England and Ireland. His close depictions of prisoners receiving death sentences or struggling to proclaim their innocence, as well as prison officers benefiting themselves through acts of violence, are therefore faithful portrayals and thus unsettling to audience members. Notably, although these characters are forced to remain in a neglected social corner, the access that Behan provided to these social minorities is presented from a humanitarian perspective, if not entirely sympathetic.

However, the conversations of inmates and warders about a number of unnamed, or behind-the-scenes, characters induce a measure of disquiet that is not directly expressed. Take the "quare," the unnamed yet central protagonist of the play, for instance. The word "quare" implies how this "queer" inmate is preconceived as a repulsive, odd or even exceptional figure, despite that he does not get to speak for himself or appear in front of the audience at any point throughout the play. The single story given to the audience regarding this unnamed, condemned character is that he has murdered his brother and will be hanged in due course. The expected execution has major effects not only on the inmates and warders but also on audience members who are constantly reminded of this act of capital punishment to be carried out before the play ends.

It can be argued that the unseen character leads to a play behind the play in which the audience hears about or imagines the condemned man and his executioner. Specifically, the audience cannot but picture the brutalities being performed off stage: "In the first place the [executioner] has his [own] back turned after the trap goes down ... Then they go out ... have their breakfast and don't come back for an hour ... Who's to know what happens in the hour your man is swinging there, maybe wriggling to himself in the pit" (Quare 547-548). Moreover, "one bloke had lived seventeen minutes at the end of a rope" (Quare 548). The graphic depictions of hanging an unseen inmate lead to feelings of horror not only on the part of the audience but also on another behind-the-scenes inmate who cannot wait for his reprieve and commits suicide in his isolated cell. 
The fear of death that surrounds all the seen and unseen characters is not produced by means of a physical act of hanging but via the sardonic dialogue of the prison officers. That is, the audience do not witness the hanging but hear about its minute details: from the executioner's measurement of the weight of the condemned man and the size of his neck, to a grave dug by his fellow inmates, and his letters to his family being destroyed because "what' $d$ be the sense of broadcasting such distressful rubbish?" (Quare 595). ${ }^{3}$ For the audience members who picture the hanging through hearing about it, the ambience is not over-macabre and it may thus prompt alienation distance between the death per se and their ability to assess the operation of this prison administration.

It can be argued that the behind-the-scenes characters in this play closely resemble certain roles in metanarratives who "increase [the spectators'] social and cultural selfconsciousness" (Waugh 3). In this play, the doomed "quare fellow," the unseen prisoners who communicate with each other by tapping pipes, the unnamed prostitutes who have little choice other than to marry warders, and a priest's illegitimate child, all incidentally provide a challenging picture of a social margin that is rarely seen by the public nor deemed worthy of mention. ${ }^{4}$ Notably, the audience, conscious of the "quare fellow's" approaching death and "the uncertainty even of this process," are forced to consider these fringe characters who have been negated and criminalized by the state, justifiably or not (Waugh 3). The critically aloof perspective that Behan devised subsequently introduces an alternative approach to the issue of whether the unseen individuals are in need of greater humanitarian attention or should be given more stringent sociological examination, and whether the death penalty is the one and only solution for furthering justice. ${ }^{5}$ It can thus be argued that what concerns the playwright lies far beyond the jail per se but has to do with behind-the-scenes matters that are thorny, unpleasant to contemplate, yet fundamental in regard to ethics and human rights. As a prison play, The Quare Fellow mirrors how "intricately structured power relations" circulate within a given society, and "how that society constructs, defines, and thus controls [and disciplines] its members," to quote Michel Foucault's observation of how human society operates (Keesey 421).

Worthy of note is Behan's challenge to the received wisdom about prisoners being socially unfit or that all behind-the-scenes characters are necessarily worthy of admiration. In other words, any categorization in a binary mode, in his view, can be problematic. For instance, a prison priest - also one of the behind-the-scenes characters - is hardly a man of compassion but "back[s] up the screws" and tells a prisoner who suffers physical pain "to think on the Lord's sufferings, then the cell door closed with a bang, leaving a smell of booze that would have tripped you up" (Quare 582).

Moreover, not all inmates deserve unconditional sympathy, for some of them would take advantage of their condemned colleague - as a matter of course - by collecting his letters and selling them to news agencies; the warders intentionally turn a blind eye to these immoral crimes that they regard as petty misdemeanors. In a word, those serving within or on behalf of this judicial system are not necessarily nobler than the prisoners but can also be morally inadequate.

The Quare Fellow presents intricate yet neglected power relations in a chaotic social corner, revealing how warders and inmates are not essentially different from the hanged man when it comes to survival issues. It can be judged that all of them behave in ways that are conditioned by powers higher than themselves, and they are fixed as social-historical beings. Nonetheless, it is important to note that those placed on different rungs of the social and power ladder can be either nonchalant or cruel towards those with less power, even within their own shared circle. The next section, exploring more underrepresented figures of the Irish Republican Army (IRA) in the mid-twentieth century, will further examine a wider social network inside and outside the prison, as well as the prejudices against the powerless in this judicial system. 


\section{The Hostage (1958): A Scapegoat on Death Row}

Compared to The Quare Fellow, The Hostage presents a greater number of diverse yet socially neglected characters, for instance prostitutes, a black homosexual, a minor civil servant and a foreign sailor, providing at least three perspectives: the characters', the spectators' and the author's, to be interrogated with a critical distance devised by the playwright.

The Hostage depicts a young English soldier, Leslie Williams, who has been captured and is under house arrest by the IRA as revenge for the upcoming execution of an 18-year-old IRA member in a Belfast jail. Like the unnamed prisoner in The Quare Fellow, this 18-yearold is also behind-the-scenes, and Leslie's fate is subject to whether the Belfast prisoner will be granted a reprieve in time. ${ }^{6}$ Unfortunately, Leslie's death occurs in the midst of "pandemonium" in the dark, and no one can tell exactly whose bullet shoots him (Hostage 106). It is ironic that, before he dies, one of his watchers, Patrick, has promised that he will be safe and "You won't die for another fifty years" (Hostage 94). A fact to be noted is that the old house where Leslie is imprisoned as a hostage has "seen its better day" but has turned into a tenement/brothel where socially marginalized individuals take refuge or rent a cheap room.

The Hostage is a controversial play for two main reasons. Firstly, this play is Behan's loose adaptation of An Giall, its original version in Gaelic, but with five more characters. ${ }^{7}$ Because An Giall received high acclaim at home in Dublin, some Irish theatre critics were very much against the English adaptation produced in London, stating that the playwright and the producer exploited "the foibles of a quaint island people for the amusement of a 'superior' British audience" (Kiberd 35). In addition, the changes in The Hostage incur "a drastic alteration of its tone," being "the destruction of the integrity of the original play" (Wall 171). Nonetheless, some others regarded the play as "one of the most total pieces of theatre to appear in London or New York since the war ... [The London] production was entirely in harmony with the exuberant, randy, free-wheeling spirit of the script" (Hogan 203). In attempting to position Behan in the European theatrical canon, Ted E. Boyle argued strongly that those who applied nineteenth-century standards to devalue Beckett, Ionesco, Osborne and Pinter, would "decry the same structure in Behan's plays" (27).

However, there should be more attention paid to the complex interpersonal relationships among the characters, their blind patriotism and the playwright's questioning of the operation of the IRA. Specifically, the socially-fringed characters that Behan created unsettle the nationalist historiography and middle-class Catholic pretences, demonstrating the empirical yet ignored reality of his country in the 1950s. In this connection, the unpleasant reality that Behan tried to construct on the stage involves a number of politically and religiously unorthodox characters. For instance, although having joined the Easter Rising, Patrick cannot wait to get rid of the label of being a hero and is happier to be "an ex-hero and present-time brothel-keeper" (Hostage 5). His identity as an IRA fighter during the Easter Rising does not mean much to him but is "out of date," as he announces in the house now serving as a whorehouse and cheap lodging for poor people (Hostage 9). In his own words, "the days of the heroes are over this forty years past. Long over, finished and done with. The IRA and the War of Independence are as dead as the Charleston" (Hostage 7).

Behan's intended breakaway from republican history, and his own former views, questions the political manipulation of individuals and the prejudice against social minorities. Notably, the socially marginalized characters - pimps, prostitutes, their clients, a homosexual naval man, a minor civil servant - face everyday difficulties that are harsh yet unseen by the mainstream public. For instance, Catholic dogmatism - as Miss Gilchrist proudly assumes - is behind the oppression of the underclass. Her condescending attitudes towards the lodgers in this brothel and her pride in working for the St. Vincent de Paul Society show Behan's concern 
for Catholic conservative elitism, thanks to which the middle-class is often better served than the needy poor. For Patrick, social workers like Miss Gilchrist are "all ex-policemen. In the old days we wouldn't go anywhere near them" (Hostage 35$){ }^{8}$

As mentioned earlier, Behan's early experiences of being jailed in England and Ireland did not prompt him to become more republican later in life; instead he became much more critical, as did some other former republican activists, of the tenor of the Free State and Irish Republic and the ongoing violence in Ireland. Notably, despite its republican attack on the unionist alternative in Belfast, The Hostage is far from being a patriotic play given its alternative characterizations of "heroes." The playwright's anti-war stance is sarcastically illustrated by portraying Leslie, the hostage, singing a highly provocative racist song (against "the Irish and the niggers and the wogs") and Meg singing a rebel song celebrating the deaths of Irish young men (Hostage 78, 80). These presentations of patriots/rebels not only exhibit the characters' insensitivity towards racial issues and lack of respect for the dead but reveal Behan's pacifism on account of, in the playwright's own words, "the sadness of Irishmen fighting Irishmen, ... because at heart I'm a pacifist" (Confessions of an Irish Rebel, 51). Behan's critical detachment from the ferment of the Republican violence on civilians is obvious throughout the play.

An almost behind-the-scenes figure worth examining is the pianist, Kate, who never speaks but sits "at one end of the passage area with the piano half on stage and half off" (Hostage 8). ${ }^{9}$ Her soothing live piano music creates not only a "drastic alteration of [the] tone" of the play (Wall 29), but also a distancing effect that counteracts the tension when "FreeStaters [fight] against Republicans, Irish against English, homosexuals against heterosexuals" (Hostage 78). This distancing effect is further strengthened when an unnamed IRA solider talks to the audience, commenting that "Brendan Behan, he's too anti-British ... He doesn't mind coming over here and taking your money" (Hostage 78). With these abrupt addresses to the audience from time to time, it can be argued that the playwright is attempting to shatter the "individual ideological consciousness" of the audience members through the play's "comic, ironic or parodic discourse" (Bakhtin 324). The play disrupts the barriers of religion, ethnicity and sectarian politics, disclosing how these social outcasts are subject to the pretences of sectarian and denominational divides in "a repressive, hypocritical, moribund, even murderous society" (Hawkins 117). In short, the hostage in the play is more than an individual by being a metaphorical representation of people trapped and manipulated by the troubled history of a divided Ireland. The next section will dwell on how the presentation of memory, or memories, and the use of the distancing effect, might critically reveal the less seen facets of a reformatory for juvenile delinquents who are forced to bear the consequences of the prolonged sectarian conflicts.

\section{Borstal Boy (1967): The Margin within the Margin}

Borstal Boy, as a theatrical production, was adapted from the novel originally published in 1958 but soon afterwards banned for unspecified reasons until 1970. Although no official reason was given for the ban, the fact remains that not only had Behan twice been imprisoned as a young man for carrying out republican missions but his work discloses the problematic prison operation as it related to juvenile inmates. ${ }^{10}$ The story features juvenile delinquents and their ambiguous sexualities, which could never find favour with the censors in puritanical Ireland. This stage adaptation was not his own work, as Behan died in 1964, but a posthumous version by Frank McMahon as an Abbey Theatre Production in 1967.

An interesting theatrical device employed in this play is the intensive use of distancing effects - with the older and younger Behans both on stage. The former often comments on what is said or explains what is unsaid, allowing the audience not to fully empathize with the characters but to observe at a distance the ups and downs of these juvenile delinquents. 
Maintaining a sense of unreality in this memory play, McMahon, the adapter, might have, on the one hand, been paying tribute to Behan; on the other hand, he might have intended to echo Behan's other plays, as the latter had used such a device, in particular, in The Hostage.

In consonance with The Quare Fellow, Borstal Boy is based upon Behan's experience in a reformatory and prisons on both sides of the Irish Sea. The political sensitivity of the play lies not only in how sectarian conflicts are staged, but the representation of teen inmates whose male bonding is not defined by existing sectarianism, class issues and religious persuasions. In keeping with Behan's other works that were critical of the Catholic Church's attitudes in favour of the middle-class and often giving only lip service to Irish independence, Borstal Boy delves further into more diverse individuals, their subjectivities, and the malfunctioning administration of a self-contained reformatory.

Borstal Boy is, as an interrogative text, difficult for hardline Catholic nationalists to accept, because the story features a mixture of Irish and English inmates who are not as antagonistic and political as might have been expected. What concerns these teenagers most is access to cigarettes, which significantly define their male bonding and masculinity. The more cigarettes one can get hold of, even just the butts, the greater the power one can obtain. The teen inmates are obviously not conditioned by a given nationality or religious persuasion but more pragmatic items. Specifically, Charlie, an English inmate, befriends whoever can spare cigarette butts: "if it's I.R.A or R.A.F., so long as 'e's got the snout" (Borstal Boy 98). ${ }^{11}$ The young Behan, although he behaves in a hostile manner towards the English inmates at the beginning of the play, recognizes that his teen peers are not as hateful as he used to think but share the same fears about the police: "In trouble with the police? Sure haven't we all been in trouble with the police?" (Borstal Boy 105).

Notably, for these youngsters whose lives are secluded from society, the heated sectarian debates in the world outside this reform institution have no practical importance for their everyday lives. For example, Christianity does not function particularly well in this space. Ironically, the best use of the Bible, for inmates, is for the rolling of cigarettes: "Smashing thin paper for rolling fags in. I must 'ave smoked my way through the Book of Genesis before I went to court" (Borstal Boy 100). The inmates' indifference to existing political divides and their pejorative attitudes towards Christianity certainly did not please the audience which had a high expectation that Behan, a former Irish republican, would write a play that was favourable to their prejudices. Nevertheless, Behan's intentional disclosure of the unseen facts of life in a reformatory implies the need to revise modern Irish history to include those genuine yet marginalized voices.

Also of interest in this semi-autobiographical play is the homosexual subtext, shown by Behan's embrace of human variety in reference to historical figures. ${ }^{12}$ When the young Behan is told by an English librarian at the Borstal that Oscar Wilde, "your wild Irishman" was jailed for homosexual lewdness, he reacts quite lukewarmly to defend Wilde: "I think that every cripple has his own way of dancing, and I think that if that shocks you, it's just as well ordinary people didn't hear about it" (Borstal Boy 100). Regardless of whether or not Behan, at the age of sixteen, did actually make this statement to justify Wilde's sexuality, he expressed candidly his sympathy for those who had been institutionally stigmatized by the mainstream. The voice of a sixteen-year-old youth might be insignificant, although on stage it can be amplified to challenge the patriarchy and homophobia embedded in English and Irish nationalisms. His statement, being politically and religiously incorrect, nonetheless illustrates Behan's attempt to challenge any kind of official history that endorses parties with vested interests.

It can thus be argued that Wilde is also one of the behind-the-scenes characters similarly to many of those in The Quare Fellow - who do not openly speak for themselves but initiate a different understanding of victims and villains. In the context of Borstal Boy, the young Behan's "blokes are only working-class kids like ourselves," as he argues to defend his 
friendships with English inmates (104). The divide between victims and villains is thus not applicable to these teenagers, nor to Wilde, who were all declared criminals by the state and unable to defend themselves.

What should be discussed further is the use of two Behans on the stage throughout the play. The older Behan is not always an indifferent commentator or observer but is sometimes eager to correct the younger Behan's mistakes and to provide supplementary information on the historical context for the audience. This fundamentally questions the use of memory in a political play, as what used to be regarded politically correct can be toppled. In addition, having already known that this play is a posthumous adaptation, the coexistence of the older and younger Behans on the same stage could cause tantalizing effects, in that the audiences could not but remain, perhaps involuntarily, detached from the conflicts - be they physical, interpersonal or conceptual - that trouble these young characters. Ostensibly, the interactions of the two Behans lead the play to become a meta-drama in which no single privileged discourse can be relied upon. The audience is given either a whole sight of the dialectic between the older and the younger or no authentic view about Behan's past. In other words, no matter whether or not the play is faithful to Behan's autobiographical novel, the dramatic adaptation demonstrates why historical or political truths cannot be possessed by one interested party but must be reached or even negated dialectically. The audience's present encounters with the deceased writer and his younger self reinforce the fact that history is not monolithic or seamless but full of discontinuities. In other words, the presence of the older Behan is not to make the writer's own recollection more convincing but to suggest that representations of many histories can be shifting and contradictory.

\section{A Trilogy in Dialogue}

The three plays under discussion all demonstrate the discrepancies between public and private histories, although Behan did not intend to claim that the private histories he presented were ultimately more reliable than any pictures of Ireland seen through the lens of the mainstream media. The distancing effects he uses in these plays unsettle the perception of the different realities as viewed by either English or Irish nationalists. By having the spectators observe the previously unseen or unnamed characters and the impending tragedies they are facing, they are given a detached position from which to examine the forgotten social minorities, and how they might have been inappropriately determined and mediated by the indifferent majorities. As a matter of fact, what confront the audiences are the brutalities and irregularities in these out-ofconsideration social corners - a space to which most viewers have little access.

The Quare Fellow provides access to the mix of problems in Irish prison administration in the 1930s and 1940s that mainstream society was not quite aware of. By exhibiting the interactions among warders, inmates and a condemned prisoner, Behan interrogates whether the judicial retribution of capital punishment can solve the problems of civil society. For him, capital punishment might be the quickest way to answer violence (i.e. with more violence), but it will never succeed in ending violence nor help in achieving understanding of its causes, be they familial or social, private or national, behind the ongoing brutalities of life. The death of the unseen character therefore prompts the audience's curiosity about the factors and dilemmas that have entrapped this person on the road to his death.

The Hostage goes further by presenting an unseen young IRA man awaiting a reprieve in Belfast. The audience can further witness how evil is returned for evil on stage. Specifically, what leads the Irish and the English into blindly killing each other is the vicious circle of violence, due to which the survival issues of socially disadvantaged characters worsen the sectarian conflicts. This aspect of inconvenient truth was rarely seen by the public in postTreaty Ireland, where an official version of history was validated and promoted in the public 
domain. Incidentally, by having a number of characters occasionally addressing the audience directly, the play strategically keeps the audience aloof from any existing political agenda that has intensified sectarian conflicts. In Behan's view, the real hostages in the play are not the ones in Dublin and Belfast but those who have no access to the darker side of revolutionary history and whose views have been intentionally suppressed for political reasons.

Borstal Boy, as mentioned earlier, was a theatrical adaptation paying posthumous tribute to Behan. This adaptation further mixes realism, alienation effects and meta-drama to disrupt the convention of constructing Irish history in a chronological manner. Instead, the play introduces two Behans, older and younger, together on the stage. Although Behan's early experiences in a reformatory are presented realistically, the presence of two Behans on the same stage suggests how history can be performative and questionable. ${ }^{13}$ Notably, the older Behan, a character not shown in Behan's autobiographical novel but a new one in this play, is given the task of questioning - often with cynicism - the reliability of the late author's reminiscences of his own past, and confessing candidly the failures of his own youth. His self-criticism thus provides a significant supplement to the official republican history that received endorsement from the government, education authorities and the media.

The three plays as a whole illuminate Behan's vision and attempt to reconstruct alternative yet inalienable views about republican operations in and out of prisons in mid twenty-century Ireland. His intention was not to stir up yet more political vehemence and antagonism by staging unseen realities but to engage the audience with the ongoing conflicts by looking through a less seen perspective. The spectators are prompted to examine the state violence that has been arbitrarily institutionalized, his means being to focus on the oppression caused to social outcasts both from above and among themselves. With the audience speculating on whether the death penalty is morally acceptable as a punishment, the replacement of violence with violence, and youth crimes, the plays form a revisionist chapter of Irish history.

\section{Notes}

${ }^{1}$ The novel Borstal Boy, Behan's autobiographical account of his teenage years as a detained juvenile offender, was first published in 1958. It was adapted as a play by Frank McMahon and staged at the Abbey Theatre in 1968 - more than three years after Behan's death.

2 The distancing effect, or the alienation effect, is a performing arts concept coined by playwright Bertolt Brecht (1898-1956). Brecht first used the term in "Alienation Effects in Chinese Acting," an essay published in 1936, in which he defined it as "playing in such a way that the audience was hindered from simply identifying itself with the characters in the play. Acceptance or rejection of their actions and utterances was meant to take place on a conscious plane, instead of, as hitherto, in the audience's subconscious" (91).

${ }^{3}$ Specifically, the name of the condemned prisoner is not engraved on his gravestone but only his prison identification number. What is ironic is that the information engraved on the gravestone is incorrect: "It should be E779 according to the book, but a '7' is easier for you to do than a '9'" (Quare 597).

${ }^{4}$ Prostitutes often marry warders for having being "dragged down to his own level” (Quare 578).

${ }^{5}$ It is believed that the prisoner who undergoes capital punishment in the play was Bernard Kirwan, who killed his own brother and became acquainted with Behan in Mountjoy Jail in Dublin. According to Behan's biographer, Seamus de Burca, "they often spoke together, and ... Kirwan embraced Brendan the day before he was hanged" (514).

${ }^{6}$ Both Behan's The Hostage and Frank O'Connor's short story, "Guests of the Nation" (1931) have Englishmen who are held captive by the Irish Republican Army and to be killed in retaliation if Irish prisoners are executed. Both works may have influenced Neil Jordan's The Crying Game, a 1992 British thriller film exploring issues of gender, race, identity, and sexuality in sectarian Ireland as its backdrop.

${ }^{7}$ An Giall was premiered on June 16, 1958 in An Damer, an Irish language theatre under the auspices of Gael Linn in Dublin. As it was well-received, Joan Littlewood invited Behan to reproduce it in English at the Theatre Royal, Stratford, London, on October 14, 1958. Nevertheless, some critics thought that Behan did not translate the play all by himself but with Littlewood's help. One critic commented that Behan was always drunk, so "whenever they wanted a change made or needed a new song, they could go across to the pub and say, 'How about it, Brendan?' That is how The Hostage got its embellishments. Half the characters in the English version were not in the Irish version" (Simpson 114). 


\begin{abstract}
${ }^{8}$ Her last name, Gilchrist, which sounds like "kill Christ," is evident of Behan's doubts about the Catholic Church and its social role. Mulleady, the elderly bi-sexual civil servant, has a name that sounds like "My Lady," or the Lady of Manor.

${ }^{9}$ However, in An Giall Kate is Patrick's consort and is more outspoken. She became a silent character in The Hostage, except for her soothing music.

${ }^{10}$ The play remained popular in Ireland and the USA, winning a Tony Award for the best play of 1970.

${ }^{11}$ R.A.F. is the abbreviation of Royal Air Force, the United Kingdom's aerial armed force established in 1918.

${ }^{12}$ Behan was married to Beatrice Salkeld in 1955 and they had one daughter. However, some critics believe that the playwright was bisexual, given the episode in the novel of coming across Charlie, a gay sailor in the British navy, having sex with another boy; the young Behan reacts nonchalantly to it and Charlie later develops feelings for him.

${ }^{13}$ What is worthy of notice is that the device of the dual Behan character in the posthumous Borstal Boy (1968) might be inspired by Brian Friel's Philadelphia Here I Come! (1964), in which the protagonist, Gar, is played by two characters which illuminate the contradictions between his public appearance and his private conscience. Both plays produce similar alienation effects to allow the audience to observe the social and personal resentments throughout the plays.
\end{abstract}

\title{
Works Cited
}

Bakhtin, Mikhail M. The Dialogic Imagination: Four Essays. Ed. Michael Holquist. Trans. Caryl Emerson and Michael Holquist. Austin: University of Texas Press, 1981.

Behan, Brendan. "The Quare Fellow". Modern Irish Drama. Ed. John P. Harrington. New York: Norton, 1991. 255-310.

_. "The Hostage". The Methuen Drama Anthology of Irish Plays. Ed. Patrick Lonergan. London: Methuen, 2008. 1-110.

- Confessions of an Irish Rebel. London: Hutchinson: 1965.

. Borstal Boy. Adpt. Frank McMahon. New York: Random, 1971.

Boyle, Ted. E. "Brendan Behan". Modern Irish Literature. Eds. Denis Lane and Carol McCrory Lane. New York: Ungar, 1988. 23-31.

Brecht, Bertolt. "A New Technique of Acting". Aspects of the Drama: A Handbook. Eds. Sylvan Barnet, Morton Berman and William Burto. Boston: Little Brown, 1962. 116-122. . "Alienation Effects in Chinese Acting". Brecht on Theatre. Ed. and trans. John Willett. New York: Hill and Wang, 1964. 91-99.

de Burca, Seamus. "Brendan Behan: A Memoir". Modern Irish Drama. Ed. John P. Harrington. New York: Norton, 1991. 513-516.

Eagleton, Terry. "History, Remembrance and Oblivion". Ireland: Space, Text, Time. Eds. Patrick Crotty, Liam Harte, Yvonne Whelan. Dublin: The Liffey Press, 2005. 3-13.

Hawkins, Maureen S. "Brendan Francis Behan (1923-1964)". Irish playwrights, 1880-1995: A Research and Production Sourcebook. Eds. Bernice Schrank and William W. Demastes. Westport, Conn.: Greenwood Press, 1997. 23-42.

. "For all the outcasts of this world': Song and Dance in Brendan Behan's An Giall and The Hostage". Irish University Review 44.1 (2014): 116-128.

Hogan, Robert. After the Irish Renaissance: A Critical History of Irish Drama since The Plough and the Stars. Minneapolis, University of Minnesota Press, 1967.

Hornby, Richard. Drama, Metadrama, and Perception. Lewisburg, Pa.: Bucknell University Press, 1986.

Jenkins, Keith. "History and Theory". The Postmodern History Reader. Ed. Jenkins, London and New York: Routledge, 1997. 384-386.

Keesey, Donald. "Historical Criticism II: Culture as Context". Contexts for Criticism. 2nd ed. Ed. Keesey. Mountain View: Mayfield, 1994. 419-427.

Kiberd, Declan. The Irish Writer and the World. Cambridge: Cambridge University Press, 2005. 
Simpson, Alan. "Behan: the Last Laugh". Brendan Behan: Interviews and Recollections. Vol. 1. Ed. E.H. Mikhail. London: MacMillan, 1982. 111-118.

Synge, J.M. Collected Works. Ed. Ann Saddlemyer. Vol. 3. Book 1. Oxford: Oxford University Press, 1968.

Tynan, Katherine. The Observer [London] 27 May 1956: 11.

Wall, Richard. "An Giall and The Hostage Compared”. Modern Drama 18.2 (1975): 165-172.

Waugh, Patricia. "What is metaficton and why are they saying such awful things about it?". Metafiction: The Theory and Practice of Self-conscious Fiction. London: Routledge, 1984. 1-19.

Wei H. Kao received his doctorate from University of Kent in 2003, and is professor of English in the Department of Foreign Languages and Literatures at National Taiwan University. He is the author of The Formation of an Irish Literary Canon in the Mid-Twentieth Century (ibidemVerlag, 2007). His articles on Irish writers have appeared in Journal of Beckett Studies, Journal of War and Culture Studies, Transnational Literature, English Studies in Africa, Iris Murdoch and Moral Imaginations (2010), Irish Women at War (2010), The Theatre of Marie Jones (2015), among others. His most recent publication is Contemporary Irish Theatre: Transnational Practices (Peter Lang, 2015).

whkao@ntu.edu.tw 